Article

\title{
Analysis of Pollution Related Deficiencies Identified through PSC Inspections for the Period 2014-2018
}

\author{
Helena Ukić Boljat ${ }^{1, *(D)}$, Merica Slišković ${ }^{1}$, Igor Jelaska ${ }^{2}$, Anita Gudelj ${ }^{1}$ and \\ Gorana Jelić Mrčelić ${ }^{1}$ \\ 1 Faculty of Maritime Studies, University of Split, 21000 Split, Croatia; merica@pfst.hr (M.S.); \\ anita@pfst.hr (A.G.); gjelic@pfst.hr (G.J.M.) \\ 2 Faculty of Kinesiology, University of Split, 21000 Split, Croatia; jelaska@kifst.hr \\ * Correspondence: hukic@pfst.hr; Tel.: +38-59-5539-6775
}

Received: 3 July 2020; Accepted: 22 July 2020; Published: 23 July 2020

check for updates

\begin{abstract}
The aim of this paper is to analyze the available data on recorded ship deficiencies during ship inspections which are related to pollution prevention. The purpose of these inspections regulated under the different Port State Control (PSC) regimes' Memorandum of Understanding (MoUs), is to detect and disable the operation of substandard ships. The data obtained were sorted according to the six Annexes of the International Convention for the Prevention of Pollution from Ships (MARPOL) Convention, and a comparison was made within the scope of each Memorandum of Understanding by each of the Annexes and antifouling system. By using a Chi-Squared test and correlation analysis, MoUs are compared and analyzed. The conclusions thus obtained provide an insight into the most common deficiencies regarding pollution prevention in the world fleet, revealing which standards are most often met and which are trying to achieve a better degree of compliance with the standards envisaged by law.
\end{abstract}

Keywords: pollution prevention; port state control; Memorandum of Understanding; ship inspections; deficiencies; MARPOL Convention

\section{Introduction}

Maritime transport is of strategic importance to the global economy. In 2017, world seaborne trade gathered momentum, with estimation of 10.7 billion tons and volumes expanding at 4 per cent, which represents the fastest growth in five years [1]. Accompanied by economic and social benefits of carrying goods by sea, pollution from ships which affects the quality of water, air, marine organisms and consequently human health, should be taken into account. Sustainable maritime transportation is a horizontal issue and, as such, is an relevant factor for most of the Sustainable Development Goals (SDG) which are stated in the 2030 Agenda for Sustainable Development [2]. In order to prevent pollution from ships and improve the safety and security of international shipping, the International Maritime Organization (IMO) is oriented to SDG 14 Life below water. In the IMO's report "Linkages Between IMO's Technical Assistance Work And The 2030 Agenda For Sustainable Development" the direct connection with each SDG is highlighted [3]. One of the crucial steps to minimize the risk posed to the marine environment is through various international and national regulations and the establishment of preventive measures. Strengthening national capacity to respond to marine pollution incidents, promotion of the ratification and enhancement of effective implementation and enforcement of International Convention for the Prevention of Pollution from Ships (MARPOL), International Convention on Oil Pollution Preparedness, Response and Co-operation (OPRC), International Convention for the Control and Management of Ships' Ballast Water and Sediments (BWM), and International Convention for the Safety of Life at Sea (SOLAS) are stated as 
direct IMO linkages with SDG 14 [3]. As shipping is a crucial factor for sustainable economic growth, it is extremely important that the safety conditions of world fleet are in accordance with the standards envisaged by law. It is of genuine importance to work on continuous improvement, development, and intensification of maritime safety legislation to prevent and eradicate substandard shipping $[4,5]$.

Worldwide, every country should ensure that each vessel which is sailing under its flag complies with the international standards. Many states and owners by fulfilling their international obligations can reduce the risk of environmental pollution, and increase the safety and protection of their passengers and their crew [4]. However, the fact is that their efforts are constantly undermined by those who do not follow the mandatory rules and use the substandard ships.

Together with previously mentioned preventive international standards, Port State Control inspections can contribute to the significant reduction of the substandard shipping [6]. International Maritime Organization defines Port State Control (PSC) as "the inspection of foreign ships in national ports to verify that the condition of the ship and its equipment comply with the requirements of international regulations and that the ship is manned and operated in compliance with these rules" [7]. A Port State Control is a general practice followed by port authorities around the world with the general aim of developing an effective and sustainable inspection mechanism [8]. Inspection is done in order to ensure that the condition of foreign ships, equipment and crew are well above the excepted level [9]. On completion of the inspection, if a ship cannot comply with the standards required by the legislative framework of the IMO, it is called a substandard ship and can be detained and deficiencies rectified $[8,10]$.

\section{Background Concept and Objectives}

The main objective of regional agreements on PSC-Memorandum of Understanding (MoU), is to eliminate the operation of substandard ships and to achieve uniformity of requirements of the ports in the same region. All existing regimes define terms under which the vessel will be marked as detained, i.e., a substandard vessel. Furthermore, the International Maritime Organization through given Procedures for Port State Control: Resolution A.787 (19), as amended by the resolution A.882 (21) [11,12] indicates that ship is regarded as substandard if the "hull, machinery, equipment, or operational safety, is substantially below the standards required by the relevant conventions or whose crew is not in conformance with the safe manning document, owing to, inter alia:

1. the absence of principal equipment or arrangement required by the conventions;

2. non-compliance of equipment or arrangement with relevant specifications of the conventions;

3. substantial deterioration of the ship or its equipment because of e.g., poor maintenance;

4. insufficiency of operational proficiency, or unfamiliarity of essential operational procedures by the crew; and

5. insufficiency of manning or insufficiency of certification of seafarers."

Annually, each PSC regime publishes the official statistical reports regarding conducted inspections, observed deficiencies, and detained vessels. The circumstances leading to detention are defined in all MoUs. The first regional agreement which brought the regulation of PSC was the Paris Memorandum of Understanding (Paris MoU) which includes Europe and the North Atlantic region. After that, PSC started to develop rapidly, and now is organized into nine regional PSCs [13] thus covering most of the ports and coastlines worldwide:

1. Paris MoU (Europe, North Atlantic region)

2. Acuerdo de Vina del Mar 1992 (Latin American region)

3. Tokyo MoU (Asia-Pacific region)

4. Caribbean $\mathrm{MoU}$ (Caribbean region)

5. Mediterranean MoU (Mediterranean region)

6. Indian Ocean MoU (Indian Ocean region) 
7. Abuja MoU (West and Central African region)

8. Black Sea MoU (Black Sea region)

9. Riyadh MoU (United Arab Emirates, Kingdom of Bahrain, Kingdom of Saudi Arabia, Sultanate of Oman, State of Qatar, State of Kuwait)

Except for the above-mentioned regional agreements, the USA conducts PSC over its territorial waters.

Through a literature review, it is evident that PSC plays a decisive role in reducing risk and ensuring maritime safety and, therefore, minimizes the risk of possible pollution [14]. Although, all regional regimes are essentially the same, there are many differences regarding ship targeting, implementation and performance of inspections $[8,10,15]$. While targeting ships, all the regimes pick certain ship types and use history of inspection and time criteria, but do not take into consideration each other's inspections as well as the inspections conducted by the industry $[15,16]$. Furthermore, the most comprehensive and strict inspections are made within the Paris MoU and Tokyo MoU, which also have the most efficient methods for selecting ships for inspection [8,13]. The Paris MoU assigns a ship risk profile in the information system THETIS. THETIS combines two groups of factors which are relevant for the determination of a Ship Risk Profile (SRP). The first group of factors is connected with general information, such as the type of ship, age of ship, flag, recognized organization, and company, while the second group includes results of previous inspections, existing deficiencies, information on detention, and the time interval between controls [17]. From another perspective, in order to "to avoid unduly detaining or delaying a ship" Tokyo MoU directs inspections according to priorities of each port authority [18].

For detailed analysis of the differences across PSC regimes, such as differences regarding deficiencies, we refer to differences based on port states or average probabilities of detention based on an inspector's background $[10,16]$. Despite the many differences between different regimes, an exchange of information on ships inspected through the unique database, unification of the standards for inspection and detention, and the training of officers who conduct inspections under the MoUs is crucial for elimination of substandard ships worldwide [19].

While the effectiveness of the port state controls inspections, and ship detentions and deficiencies under various MoUs for the determination of the effect of the PSC on maritime safety have been well investigated in previous studies $[10,15,16]$, there is a lack of statistical analysis regarding detected pollution prevention deficiencies. Furthermore, there is no available mutual comparison of the positive MoUs worldwide in terms of identified pollution regarding deficiencies.

Some of the following ship sources pollutants which have a harmful effect on the marine environment are exhaust gases (sulfur, nitrogen, carbon dioxide), toxic anti-fouling paint, the noise from ships, garbage and sewage from ships, cargo residues, chemical effluents from tankers, oil spills, and ballast water. Moreover, each of the MARPOL Annexes as they are subject to the PSC inspection are analyzed. Through the MARPOL Annex I to VI major pollutants from ships such as oil (Annex I), harmful substances (Annex II and III), sewage (Annex IV), garbage (Annex V), and exhaust gases (VI) are regulated.

The research problem involves the identification of a global unique pollution related deficiencies database. The background goal is to investigate the availability of validated data through all memoranda related to pollution. The aim of this paper is to analyze and compare pollution-related non-conformities that are observed through regular PSCs by each MoU for the five-year period, 2014-2018. In the following chapter the PSC regime will be explained in more detail. Furthermore, the main hypothesis investigated throughout this paper is that higher numbers of inspections detect higher numbers of pollution-related deficiencies. The methodology of the research includes:

1. analysis of the total number of identified deficiencies by using available MoU data on PSC;

2. identification of the deficiencies for nine regional agreements on PSC;

3. categorization of the deficiencies by the 6 Annexes of the MARPOL convention; 
4. antifouling systems and MARPOL-related operational deficiencies; and

5. comparison of the gathered data for 2014-2018 period.

Since the presentation of data through nine different memoranda is not standardized, and the fact that some regimes carry out more stringent inspections, when reaching conclusions, possible variations in quality and inspection dynamics should be taken into account.

\section{Materials and Methods}

For analyzing the data regarding pollution, annual statistical reports of nine MoUs for the period from 2014 to 2018 were used [20-62].

The analysis was not focused on the previous ship inspections, nor was it focused on the time interval between the two inspections. Although it can provide specific insights into the data analysis, due to the fact that those data are inaccessible, they were not integrated as a fundamental part of the study and can be considered as a limitation of the study. Furthermore, it should be underlined that records with missing data are considered as "average" (i.e., not to be identified as "outlier" data) and will not crucially impact on the provided statistical analysis.

1. The data extracted from each organization follows: number of inspections;

2. number of observed deficiencies in total;

3. number of observed deficiencies in category of pollution prevention; and

4. number of observed deficiencies for each MARPOL Annex;

5. antifouling and MARPOL-related operational deficiencies.

For Mediterranean MoU the data regarding the number of observed deficiencies will be presented, but the detailed analysis of observed deficiencies through the 6 Annexes of the MARPOL could not be given due to a lack of data.

All data was presented as mean \pm standard deviation together with a coefficient of variation and minimal and maximal result. Furthermore, due to the identification of relationships between the number of deficiencies and the number of inspections for each observed year, Pearson's coefficient of linear correlation was calculated together with the coefficient of determination, $t$-value and level of statistical significance. Additionally, for each year a linear regression model was applied to identify relationships between the number of deficiencies and the number of inspections. A $\chi 2$ test was used to test the significance of differences among proportions of the MARPOL in deficiencies for nine regional PSC regimes within each year and the significance of differences among proportions of the MARPOL in deficiencies within each regional PSC regime between years. For all statistical analysis, Type I error was set at $\alpha=5 \%$. All calculations were done by using the data analysis software system Statistica 13.0. (Dell Inc, Tulsa, OK, USA).

\section{Results and Discussion}

According to the available annual statistical reports for all nine MoUs, the number of total observed deficiencies for the period 2014-2018 was extracted and given in Figure 1.

According to the data presented in Figure 1, the largest number of deficiencies was recorded in Tokyo MoU. In 2014, there were 86,560 deficiencies recorded. During the four-year period that number decreased and in 2018, 73,441 deficiencies were observed. It is important to highlight that in the Tokyo MoU the top three categories of deficiencies discovered through ship's inspections were: fire safety measures, the safety of navigation, and life-saving equipment. Furthermore, regarding pollution prevention deficiencies in the Tokyo MoU, statistics showed that in the top 10 most frequent detainable deficiencies were oil filters and sewage treatment plants [58-62]. 


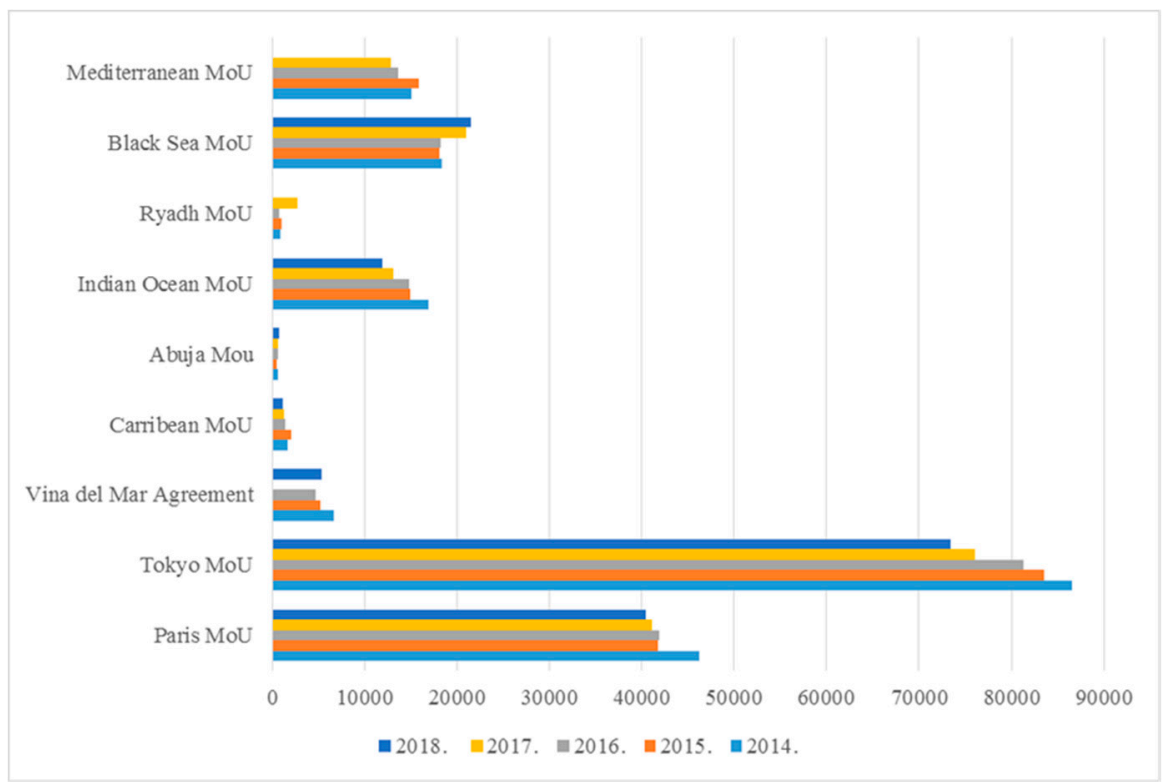

Figure 1. Overview of observed deficiencies in total through MoUs in the period 2014-2018. Source: Made by authors according data extracted from statistical reports.

After the Tokyo MoU, the largest number of deficiencies was recorded in the Paris MoU, with twice the smaller number of identified deficiencies in the Tokyo MoU. In 2014, the number of identified deficiencies in Paris MoU were 46,224, and after the four-year period, that number also decreased to 40,368. Regarding pollution prevention deficiencies in the Paris MoU, the total number of deficiencies recorded was 2401. The increase in the number of deficiencies compared to 2017 (1949 deficiencies) can be explained by the new requirements resulting from the Ballast Water Management Convention. It should be noted that Oil Record Book is listed in the top five observed deficiencies in the Paris MoU (661 deficiencies regarding Oil Record Book in 2018) [49-53].

When comparing the figures, it is important to state the fact that the range of observed deficiencies through different MoUs is so large because the number of conducted inspections differ. For example, the Tokyo MoU recorded the largest number of deficiencies, but if we compare the number of conducted inspections between the Tokyo MoU and the Paris MoU, it is notable that a larger number of inspections were conducted within the Tokyo MoU. In 2018, 30,405 inspections were conducted within Tokyo MoU. In the same year, within the Paris MoU, there were 17,952 inspections [53,62].

Furthermore, it can be seen that the smallest number of observed deficiencies was recorded in the Abuja MoU and the Caribbean MoU. In 2018 within the Abuja MoU, 2409 inspections were conducted with 727 observed deficiencies [46]. Within the Caribbean MoU for 2018, there were 635 inspections with 1186 observed deficiencies [34].

Comparison of the data for all MoUs in relation to the frequency and the type of deficiencies in the context of the VI Annexes of the MARPOL Convention and Antifouling for the period 2014-2018 is shown in the Table 1.

Since the largest number of conducted inspections and recorded deficiencies is within the Paris and the Tokyo MoU, the largest number of deficiencies related to the six Annexes of the MARPOL Convention is also within these two regimes. The largest number of deficiencies is related to the Annex I of the MARPOL Convention, followed by Annexes V, VI, and IV (ratings differ from MoU to MoU). In other segments of the pollution prevention results are below $1 \%$ of the total number of deficiencies. 
Table 1. Observed deficiencies for pollution prevention through MoU in the period 2014-2018.

\begin{tabular}{|c|c|c|c|c|c|c|c|c|}
\hline MoU & Annex I & Annex II & Annex III & Annex IV & Annex V & Annex VI & Anti-Fouling & Grand Total \\
\hline Abuja Total & 116 & 0 & 4 & 18 & 28 & 7 & 1 & 174 \\
\hline 2014 & 26 & 0 & 2 & 0 & 7 & 2 & 0 & 37 \\
\hline 2015 & 16 & 0 & 0 & 1 & 4 & 2 & 0 & 23 \\
\hline 2017 & 25 & 0 & 1 & 2 & 2 & 0 & 0 & 30 \\
\hline 2018 & 25 & 0 & 1 & 12 & 12 & 1 & 0 & 51 \\
\hline 2015 & 251 & 3 & 6 & 73 & 200 & 18 & 0 & 551 \\
\hline 2016 & 293 & 11 & 6 & 52 & 178 & 19 & 1 & 560 \\
\hline 2017 & 359 & 1 & 8 & 67 & 279 & 22 & 1 & 737 \\
\hline 2018 & 256 & 4 & 13 & 55 & 312 & 83 & 1 & 724 \\
\hline Caribbean Total & 126 & 0 & 1 & 83 & 50 & 14 & 0 & 283 \\
\hline 2018 & 23 & 0 & 1 & 23 & 10 & 2 & 0 & 60 \\
\hline Indian Ocean Total & 1524 & 7 & 14 & 1357 & 929 & 513 & 4 & 4348 \\
\hline 2014 & 283 & 0 & 10 & 293 & 204 & 110 & 0 & 900 \\
\hline 2015 & 360 & 0 & 0 & 319 & 197 & 84 & 1 & 961 \\
\hline 2016 & 327 & 2 & 1 & 299 & 174 & 117 & 1 & 921 \\
\hline 2017 & 255 & 1 & 2 & 245 & 157 & 81 & 2 & 743 \\
\hline 2018 & 299 & 4 & 1 & 201 & 197 & 121 & 0 & 823 \\
\hline Paris Total & 3645 & 85 & 28 & 1718 & 2990 & 2475 & 50 & 10,991 \\
\hline 2014 & 875 & 27 & 4 & 346 & 598 & 459 & 17 & 2326 \\
\hline 2015 & 810 & 16 & 5 & 338 & 609 & 471 & 10 & 2259 \\
\hline 2016 & 708 & 16 & 4 & 336 & 551 & 428 & 13 & 2056 \\
\hline Tokyo Total & 7871 & 101 & 98 & 6086 & 6688 & 4959 & 65 & 25,868 \\
\hline 2014 & 1679 & 13 & 33 & 1199 & 1587 & 758 & 7 & 5276 \\
\hline 2015 & 1607 & 17 & 30 & 1301 & 1252 & 847 & 13 & 5067 \\
\hline 2016 & 1609 & 25 & 12 & 1199 & 1162 & 845 & 7 & 4859 \\
\hline 2017 & 1468 & 30 & 10 & 1131 & 1014 & 886 & 22 & 4561 \\
\hline 2018 & 1508 & 16 & 13 & 1256 & 1673 & 1623 & 16 & 6105 \\
\hline $\begin{array}{l}\text { Vina del mar } \\
\text { Agreement Total }\end{array}$ & 387 & 0 & 3 & 110 & 854 & 108 & 10 & 1472 \\
\hline 2014 & 0 & 0 & 0 & 0 & 0 & 0 & 0 & 0 \\
\hline 2015 & 135 & 0 & 1 & 32 & 255 & 27 & 0 & 450 \\
\hline 2016 & 112 & 0 & 1 & 30 & 283 & 29 & 3 & 458 \\
\hline 2017 & 0 & 0 & 0 & 0 & 0 & 0 & 0 & 0 \\
\hline 2018 & 140 & 0 & 1 & 48 & 316 & 52 & 7 & 564 \\
\hline Grand Total & 15,296 & 227 & 187 & 9745 & 12,788 & 8244 & 137 & 46,776 \\
\hline
\end{tabular}

It is interesting to note that some regimes extract detailed data and specify the percentage of deficiencies. In 2018, in the Vina del Mar Agreement, 5365 deficiencies were discovered, of which the MARPOL deficiencies count 564 , almost $10 \%$ of the total number. The most common deficiency discovered in this region is garbage, i.e., analyzing the available reports it is evident that in the Vina del Mar Agreement the largest number of deficiencies is in the domain of the Annex V which deals with garbage and waste management.

In the Mediterranean MoU report, there is no available data on observed deficiencies for each MARPOL Annex, but it is possible to extract some concise data regarding pollution prevention. In 2014, in this region there were 15,092 recorded deficiencies; of which $3 \%$ were in the domain of pollution prevention. In 2015, the number of deficiencies increased slightly to 15,823 , but the percentage of pollution prevention deficiencies remained the same (3\%). Furthermore, in 2016 the 
number of deficiencies decreased to 13,585; of which the pollution prevention deficiencies are the same in percentages (3\%). Following the same pattern from 2016, in 2017 the number of deficiencies decreased to 12,786 ; but it is noticeable that the pollution prevention deficiencies increased by $4 \%$. There are no available data for 2018 [40-43].

Interesting results regarding MARPOL-related deficiencies are also recorded within the Abuja MoU. Comparing percentages of pollution prevention deficiencies in the period 2016-2018 the increase in pollution related deficiencies is noted (from 5.15\% in 2016 to $7.02 \%$ in 2018.). The largest number of observed anomalies is connected with the Annex I [46-48]. In the Riyadh MoU, the most interesting category for observation are the MARPOL-related operational deficiencies, giving the fact that for other memoranda there are no available data. In 2016 within the Riyadh MoU, the total number of recorded deficiencies was 742, of which the largest number is connected to the MARPOL-related operational deficiencies, which is in fact 81 (approximately 10\% of the total number). For 2017 and 2018 there are no available data regarding the MARPOL-related operational deficiencies.

In Table 2, descriptive statistics of the total number of deficiencies, the total number of inspections, and identified pollution prevention deficiencies independently from regional PSC regimes for the period 2014-2016 is presented.

Table 2. Descriptive statistics of the total number of deficiencies, the total number of inspections and identified pollution prevention deficiencies for the period 2014-2018: mean \pm standard deviation (Mean $\pm \mathrm{SD}$ ), coefficient of variation ( $\mathrm{CV} \%)$, minimal (Min) and maximal result (Max) of all memoranda through years.

\begin{tabular}{cccccc}
\hline & & Mean \pm SD & CV\% & Min & Max \\
\hline \multirow{2}{*}{2014} & \#Def & $21,414.44 \pm 28,280.37$ & 132.06 & 609 & 86,560 \\
& \#Ins & $9117.67 \pm 9471.17$ & 103.88 & 836 & 30,405 \\
& \#MARPOL & $1325.86 \pm 1920.65$ & 144.861 & 37 & 5276 \\
\hline \multirow{2}{*}{2015} & \#Def & $20,321.56 \pm 27,042.93$ & 133.08 & 528 & 83,606 \\
& \#Ins & $9168.22 \pm 9673.48$ & 105.51 & 867 & 31,407 \\
& \#MARPOL & $1188.13 \pm 1729.31$ & 145.55 & 23 & 5067 \\
\hline \multirow{2}{*}{2016} & \#Def & $19,695.33 \pm 26,524.28$ & 134.67 & 642 & 81,271 \\
& \#Ins & $9873.11 \pm 9869.12$ & 99.96 & 859 & 31,678 \\
& \#MARPOL & $1135.88 \pm 1643.61$ & 144.70 & 33 & 4859 \\
\hline \multirow{2}{*}{2018} & \#Def & $20,639.17 \pm 24,511.76$ & 118.76 & 611 & 80,284 \\
& \#Ins & $9774.36 \pm 8823.76$ & 90.27 & 859 & 31,678 \\
& \#MARPOL & $1211.82 \pm 1529.37$ & 126.20 & 34 & 4456 \\
\hline & \#Def & $19,695.33 \pm 26,524.28$ & 134.92 & 692 & 79,287 \\
& \#Ins & $9873.11 \pm 9869.12$ & 99.96 & 887 & 29,608 \\
& \#MARPOL & $1274.81 \pm 1266.19$ & 99.32 & 36 & 4711 \\
\hline
\end{tabular}

When analyzing Table 2, it can be concluded that the variability of observed deficiencies, calculated by the coefficient of variation throughout years is large. This is clearly due to the fact that the number of conducted inspections differ in different MoUs.

On the other side, in Table 3, descriptive statistics of the identified pollution prevention deficiencies (MARPOL-related) within nine regional PSC regimes independently from the time period is presented.

Contrary to the data from Table 2, variability of deficiencies regarding MARPOL within particular MoUs is relatively small. It can be noted that there are large differences among different MoUs, for example Paris vs. the Caribbean. It is clearly due to the amount of maritime traffic in those areas.

Furthermore, due to the identification of relationships between the number of deficiencies and the number of inspections, Pearson's coefficient of correlation for each year was calculated (Table 4). 
Table 3. Descriptive statistics of the identified pollution prevention deficiencies (MARPOL-related) within nine regional PSC regimes: mean \pm standard deviation (Mean \pm SD), coefficient of variation $(\mathrm{CV} \%)$, minimal (Min) and maximal result (Max) of all memoranda through years.

\begin{tabular}{|c|c|c|c|c|c|}
\hline & & Mean \pm SD & $\mathrm{CV} \%$ & Min & Max \\
\hline \multirow{3}{*}{ Paris } & \#Def & $42,270.2 \pm 2290$ & $5.42 \%$ & $40,368.00$ & $46,224.00$ \\
\hline & \#Ins & $18,013.8 \pm 262.46$ & $1.46 \%$ & $17,840.00$ & $18,477.00$ \\
\hline & \#MARPOL & $2198.2 \pm 189.39$ & $8.62 \%$ & 1949.00 & 2401.00 \\
\hline \multirow{3}{*}{ Tokyo } & \#Def & $80,197.2 \pm 5376.48$ & $6.70 \%$ & $73,441.00$ & $86,560.00$ \\
\hline & \#Ins & $31,278.8 \pm 509.13$ & $1.63 \%$ & $30,405.00$ & $31,678.00$ \\
\hline & \#MARPOL & $5388.2 \pm 873.73$ & $16.22 \%$ & 4822.00 & 6917.00 \\
\hline \multirow{3}{*}{ Vina del Mar } & \#Def & $5441.75 \pm 2543.56$ & $46.74 \%$ & 4612.00 & 6631.00 \\
\hline & \#Ins & $8471.8 \pm 678.81$ & $8.01 \%$ & 7739.00 & 9366.00 \\
\hline & \#MARPOL & $386.5 \pm 253.88$ & $55.53 \%$ & 450.00 & 564.00 \\
\hline \multirow{3}{*}{ Carribean } & \#Def & $1518.8 \pm 330.85$ & $21.78 \%$ & 1186.00 & 2047.00 \\
\hline & \#Ins & $793.2 \pm 96.46$ & $12.16 \%$ & 635.00 & 867.00 \\
\hline & \#MARPOL & $69.75 \pm 33.21$ & $47.61 \%$ & 60.00 & 89.00 \\
\hline \multirow{3}{*}{ Abuja } & \#Def & $618.6 \pm 73.48$ & $11.88 \%$ & 528.00 & 727.00 \\
\hline & \#Ins & $2333.8 \pm 381.41$ & $16.34 \%$ & 1922.00 & 2916.00 \\
\hline & \#MARPOL & $34.8 \pm 10.4$ & $29.89 \%$ & 23.00 & 51.00 \\
\hline \multirow{3}{*}{ Indian Ocean } & \#Def & $14,307.8 \pm 1913.23$ & $13.37 \%$ & $11,847.00$ & $16,856.00$ \\
\hline & \#Ins & $5938.6 \pm 248.41$ & $4.18 \%$ & 5674.00 & 6253.00 \\
\hline & \#MARPOL & $872.2 \pm 84.16$ & $9.65 \%$ & 747.00 & 961.00 \\
\hline \multirow{3}{*}{ Riyadh } & \#Def & $1300.75 \pm 992.29$ & $76.29 \%$ & 742.00 & 2687.00 \\
\hline & \#Ins & $3627.25 \pm 1673.53$ & $46.14 \%$ & 3104.00 & 4165.00 \\
\hline & \#MARPOL & $114.5 \pm 63.97$ & $55.87 \%$ & 58.00 & 162.00 \\
\hline \multirow{3}{*}{ Black Sea } & \#Def & $19,433.2 \pm 1648.51$ & $8.48 \%$ & $18,094.00$ & $21,450.00$ \\
\hline & \#Ins & $5096.2 \pm 78.89$ & $1.55 \%$ & 4997.00 & 5214.00 \\
\hline & \#MARPOL & $636.8 \pm 89.48$ & $14.05 \%$ & 551.00 & 739.00 \\
\hline \multirow{3}{*}{ Mediterranean } & \#Def & $14,321.5 \pm 6515.99$ & $45.50 \%$ & $12,786.00$ & $15,823.00$ \\
\hline & \#Ins & $5325.25 \pm 2395.35$ & $44.98 \%$ & 5049.00 & 5740.00 \\
\hline & \#MARPOL & $\mathrm{n} / \mathrm{a}$ & n/a & $\mathrm{n} / \mathrm{a}$ & $\mathrm{n} / \mathrm{a}$ \\
\hline
\end{tabular}

Table 4. Pearson's coefficient of correlation between number of deficiencies and no of inspections $r$-coefficient of correlation, $r^{2}$-coefficient of determination, $t$-value, $p$-level of significance.

\begin{tabular}{cccccc}
\hline & $\mathbf{2 0 1 4}$ & $\mathbf{2 0 1 5}$ & $\mathbf{2 0 1 6}$ & $\mathbf{2 0 1 7}$ & $\mathbf{2 0 1 8}$ \\
\hline $\boldsymbol{r}$ & 0.965 & 0.967 & 0.946 & 0.947 & 0.934 \\
$\boldsymbol{r}^{2}$ & 0.932 & 0.934 & 0.895 & 0.897 & 0.872 \\
$\boldsymbol{t}$ & 9.808 & 9.986 & 7.741 & 8.342 & 9.932 \\
$\boldsymbol{p}$ & $<0.001$ & $<0.001$ & $<0.001$ & $<0.001$ & $<0.001$ \\
\hline
\end{tabular}

The correlation between the number of deficiencies and the number of inspections is pointing to the fact that the larger number of inspections is not related to the smaller number of deficiencies. The example of a graphical linear regression model is given for 2014 (Figure 2), due to the fact that models for other years would be similar. A large statistical correlation between the number of inspections and the number of deficiencies can be noted.

Finally, by using a $\chi 2$ test, the significance of differences within each year among nine regional PSC regimes was examined. On the other side, the significance of differences within each regional PSC regimes among years were examined (Table 5). 


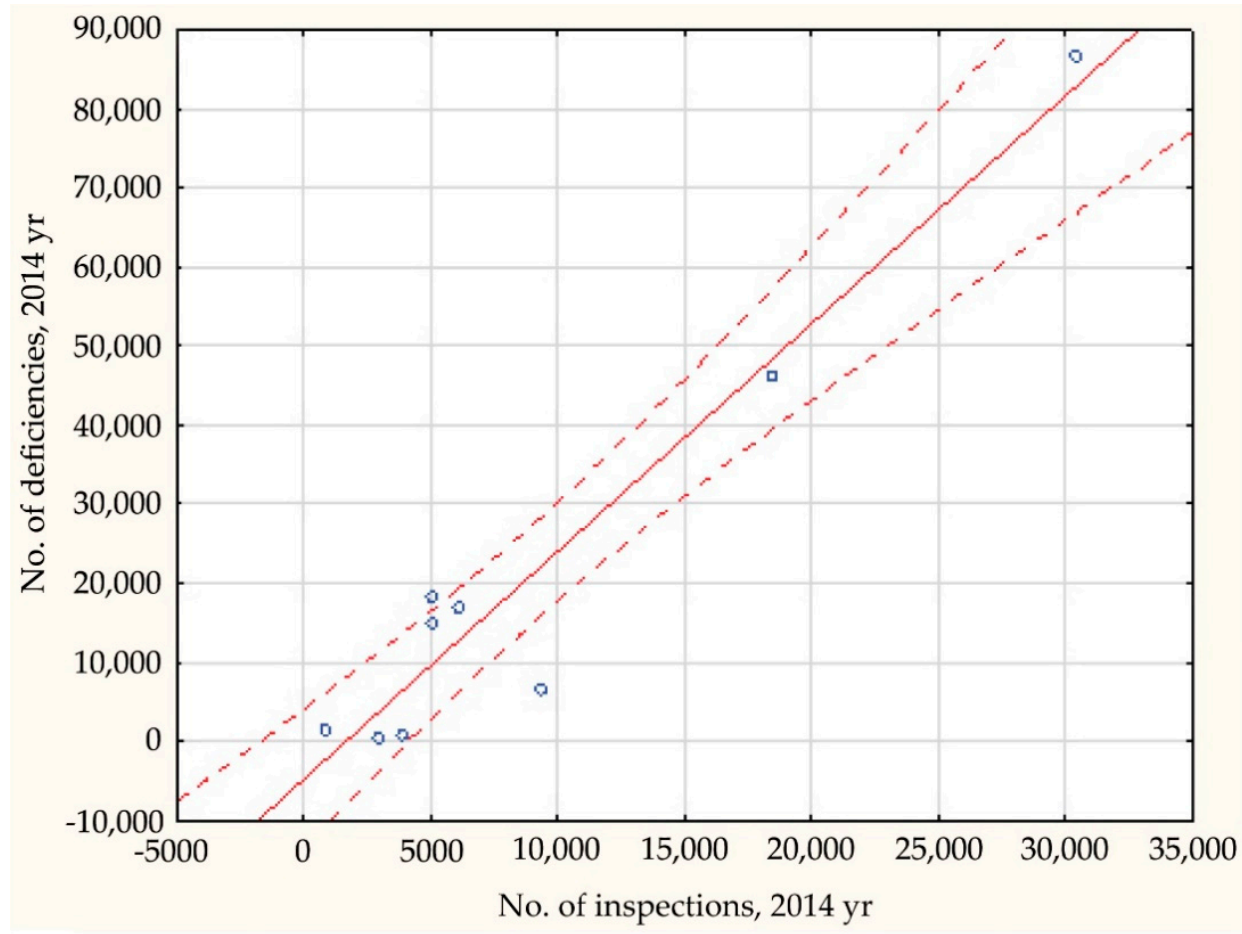

Figure 2. Linear regression model for 2014.

Table 5. Significance of differences within each year among nine regional PSC regimes and within each regional PSC regime among years examined by a $\chi^{2}$ test.

\begin{tabular}{|c|c|c|c|c|c|c|}
\hline & 2014 & 2015 & 2016 & 2017 & 2018 & \\
\hline Paris & 0.05 & 0.05 & 0.05 & 0.05 & 0.06 & $\begin{array}{c}x^{2}(4)=72.83 \\
p<0.001\end{array}$ \\
\hline Tokyo & 0.06 & 0.06 & 0.06 & 0.06 & 0.09 & $\begin{array}{c}\chi 2(4)=983.534 \\
p<0.001\end{array}$ \\
\hline Vina del Mar & 0.01 & 0.09 & 0.10 & $\mathrm{n} / \mathrm{a}$ & 0.11 & $\begin{array}{c}x 2(3)=514.32 \\
p<0.001\end{array}$ \\
\hline Carribean & $\mathrm{n} / \mathrm{a}$ & 0.04 & 0.05 & 0.05 & 0.05 & $\begin{array}{c}\chi 2(3)=0.874 \\
p=0.832\end{array}$ \\
\hline Abuja & 0.06 & 0.04 & 0.05 & 0.05 & 0.07 & $\begin{array}{c}\chi 2(4)=4.77 \\
p=0.311\end{array}$ \\
\hline Indian Ocean & 0.05 & 0.06 & 0.06 & 0.06 & 0.07 & $\begin{array}{c}\chi^{2}(4)=39.17 \\
p<0.001\end{array}$ \\
\hline Riyadh & 0.07 & 0.11 & 0.18 & 0.06 & $\mathrm{n} / \mathrm{a}$ & $\begin{array}{c}x 2(3)=101.75 \\
p<0.001\end{array}$ \\
\hline Black Sea & 0.03 & 0.03 & 0.03 & 0.04 & 0.03 & $\begin{array}{c}x^{2}(4)=9.93 \\
p=0.042\end{array}$ \\
\hline \multirow[t]{2}{*}{ Mediterannean } & $\mathrm{n} / \mathrm{a}$ & $\mathrm{n} / \mathrm{a}$ & $\mathrm{n} / \mathrm{a}$ & $\mathrm{n} / \mathrm{a}$ & $\mathrm{n} / \mathrm{a}$ & \\
\hline & $\begin{array}{c}x^{2}(6)=471.52 \\
p<0.001\end{array}$ & $\begin{array}{c}x^{2}(7)=402.60 \\
p<0.001\end{array}$ & $\begin{array}{c}x^{2}(7)=638.85 \\
p<0.001\end{array}$ & $\begin{array}{c}\chi^{2}(6)=295.48 \\
p<0.001\end{array}$ & $\begin{array}{c}\chi^{2}(6)=991.54 \\
p<0.001\end{array}$ & \\
\hline
\end{tabular}

Differences among MoUs are significant for all observed years, while within the same MoU differences among years are identified only in Riyadh, the Indian Ocean, Paris, and Tokyo. Regarding Paris, the significance of the differences among proportions (which are practically the same, 0.05 ) is very probably due to the large number of observed deficiencies. It can be highlighted that throughout all observed years, Riyadh has the largest proportion of deficiencies.

\section{Conclusions}

Although each organization gives the annual statistical report, there are differences in the presentation of the data; for example, the Mediterranean MoU publishes data but does not sort them in the same way as the other organizations. It can be pointed out that the Member States comply with the agreements signed, and controls are performed regularly and in accordance with the requirements of 
the Convention, i.e., during inspections, the inspectors seek, observe, and report deficiencies related to all six Annexes of the MARPOL Convention.

Furthermore, the number of reported deficiencies in certain areas of pollution of ships is in line with the number of controls and inspections, i.e., the number increases or decreases in proportion to the number of inspections carried out; therefore, despite the visible discrepancy in the number of recorded deficiencies among regimes, the percentage is similar or approximately similar to all MoUs. Comparing all the six Annexes across all MoUs, the largest number of observed deficiencies in all MoUs is recorded for requirements and standards provided in the Annex I of the MARPOL Convention. The number of detected deficiencies after the Annex I is followed by the percentage of the MARPOL Annex V, IV, and VI. These are mostly the emissions of sulfur oxide, then deficiencies in operating procedures, notes on the delivery of bunkers, and incinerator operation and documentation. Moreover, they are followed by substandard technical files and control, fuel quality, and emissions of substances that destroy the ozone layer. Deficiencies which are regulated with Annex II and III, as well as deficiencies in antifouling, are represented in all inspections at least. For Antifouling and MAPROL-related operational deficiencies, in some reports there are no available data at all.

The obtained results can be useful information to all key stakeholders in the maritime industry, who are continuously browsing for data, such as port authorities, flag and port States, government agencies, charterers, insurers, and classification societies.

Comparison of the ship inspections gives an insight into the most often repeated deficiencies. When deficiencies are identified, it is possible to make a risk assessment for each pollutant. In practice, the risk assessment can be used as an input for creating inspection lists and priorities.

In the majority of the MoUs, it is possible to monitor statistics for recent years. Some regimes in their annual reports compare findings to at least one previous year and, thus, perceive and emphasize trends (decrease or increase) in the number of deficiencies in each segment. Most of the MoUs in their reports give detailed analysis of flags and countries for which deficiencies are reported, while there are a lack of data of the type of deficiencies that are recorded.

The variability of deficiencies regarding the MARPOL within each particular MoU is relatively small, but there are large differences among different MoUs noted. Correlation between the number of deficiencies and number of inspections points to the fact that the larger number of inspections is not related to the smaller number of deficiencies.

Although, deficiencies regarding the MARPOL Convention are less common, there is always a risk of those who do not follow the mandatory rules and use substandard ships. In line with sustainable shipping, worldwide vessels should be in compliance with the international standards, which, together with regular port inspections, can minimize the risk of pollution and increase the safety of passengers and the crew.

Accompanied by stakeholder awareness, raising public awareness regarding substandard ships is a crucial step for the minimization of the risks posed to the marine environment.

Author Contributions: For "Conceptualization", authors namely H.U.B., M.S., G.J.M. For "Methodology" H.U.B., M.S., G.J.M. For "Investigation" M.S. For "writing—original draft preparation" authors namely H.U.B., M.S., G.J.M. For "data curation" H.U.B. For "formal analysis" I.J. and A.G. For "writing—review and editing", authors namely: H.U.B., M.S., A.G. For supervision: M.S. All authors have read and agreed to the published version of the manuscript.

Funding: This research received no external funding.

Acknowledgments: In this section you can acknowledge any support given which is not covered by the author contribution or funding sections. This may include administrative and technical support, or donations in kind (e.g., materials used for experiments).

Conflicts of Interest: The authors declare no conflict of interest. 


\section{References}

1. United Nations Conference on Trade and Development (UNCTAD). Review of Maritime Transport 2018; United Nations: New York, NY, USA, 2018.

2. Unted Nations. The Sustainable Development Goals. Available online: https://www.un.org/ sustainabledevelopment/development-agenda/ (accessed on 1 October 2017).

3. International Maritime Organization (IMO). Linkages Between Imo's Technical Assitance Work and the 2030 Agenda For Sustainable Development; IMO: New York, NY, USA, 2018.

4. European Commission. Mobility and Transport. Available online: https://ec.europa.eu/transport/modes/ maritime/safety_en (accessed on 1 October 2017).

5. Emecen Kara, E.G.; Oksas, O.A. Comparative analysis of regional agreements on port state control. Am. Sci. Res. J. Eng. Technol. Sci. 2016, 18, 259-270.

6. Knapp, S.; Bijwaard, G.; Heij, C. Estimated incident cost savings in shipping due to inspections. Accid. Anal. Prev. 2011, 43, 1532-1539. [CrossRef] [PubMed]

7. International Maritime Organization (IMO). Port State Control. Available online: http://www.imo.org/en/ ourwork/msas/pages/portstatecontrol.aspx (accessed on 5 July 2017).

8. Emecen Kara, E.G. Risk assessment in the Istanbul Strait using Black Sea MOU port state control inspections. Sustainability 2016, 8, 390. [CrossRef]

9. Ravira, F.J.; Piniella, F. Evaluating the impact of PSC inspector's professional profile: A case study of the Spanish Maritime Administration. WMU J. Marit. Aff. 2016, 15, 221-236. [CrossRef]

10. Knapp, S.; Franses, P.H. Comprehensive review of the maritime safety regimes: Present status and recommendations for improvements. Trans. Rev. 2010, 30, 241-270. [CrossRef]

11. International Maritime Organization (IMO). Resolution A.787(19): Procedures For Port State Control; IMO: New York, NY, USA, 1995.

12. International Maritime Organization (IMO). Resolution A.882(21): Amendments to the Procedures For Port State Control (Resolution A.787(19)); IMO: New York, NY, USA, 2000.

13. Li, K.X.; Zheng, H. Enforcement of law by the port state control (PSC). Marit. Policy Manag. 2008, 35, 61-71. [CrossRef]

14. Meija, M., Jr.; Cariou, P.; Wolf, F.C. Vessels at Risk and the Effectiveness of Port State Control Inspections; Laboratoire d'Economie et de Management Nantes-Atlantique Université de Nantes: Nantes, France, 2010.

15. Heij, C.; Bijwaard, G.E.; Knapp, S. Ship inspection strategies: Effects on maritime safety and environmental protection. Trans. Res. Part D Trans. Environ. 2011, 16, 42-48. [CrossRef]

16. Knapp, S.; Franses, P.H. A Global view on port state control: Econometric Analysis Of The Differences Across Port State Control Regimes. Marit. Policy Manag. 2007, 34, 453-482. [CrossRef]

17. Nikcevic, J. Montenegro on the path to Paris MoU accession: Towards achieving a sustainable shipping industry. Sustainability 2018, 10, 1900. [CrossRef]

18. McDorman, T.L. Regional port state control agreements: Some issues of international law. Ocean Coast Law J. 2000, 5, 207-226.

19. Mehrotra, D. Memorandums of Understanding on Port State Control: The Need for a Global MOU? World Maritime University: Malmö, Sweden, 2000.

20. ClassNK Annual Report on Port State Control. In Acuerdo Viña del Mar 1992: Annual Report on Port State Control- Latin American Agreement 2014; Nippon Kaiji Kyokai Survey Department: Tokyo, Japan, 2014.

21. ClassNK Annual Report on Port State Control. In Acuerdo Viña del Mar 1992: Annual Report on Port State Control- Latin American Agreement 2015; Nippon Kaiji Kyokai Survey Department: Tokyo, Japan, 2015.

22. ClassNK Annual Report on Port State Control. In Acuerdo Viña del Mar 1992: Annual Report on Port State Control- Latin American Agreement 2016; Nippon Kaiji Kyokai Survey Department: Tokyo, Japan, 2016.

23. ClassNK Annual Report on Port State Control. In Acuerdo Viña del Mar 1992: Annual Report on Port State Control- Latin American Agreement 2017; Nippon Kaiji Kyokai Survey Department: Tokyo, Japan, 2017.

24. ClassNK Annual Report on Port State Control. In Acuerdo Viña del Mar 1992: Annual Report on Port State Control- Latin American Agreement 2018; Nippon Kaiji Kyokai Survey Department: Tokyo, Japan, 2018.

25. Black Sea Memorandum of Understanding on Port State. In Port State Control In The Black Sea Region-Annual Report 2014; Black Sea MoU: Istanbul, Turkey, 2014. 
26. Black Sea Memorandum of Understanding on Port State. In Port State Control In The Black Sea Region-Annual Report 2015; Black Sea MoU: Istanbul, Turkey, 2015.

27. Black Sea Memorandum of Understanding on Port State. In Port State Control In The Black Sea Region-Annual Report 2016; Black Sea MoU: Istanbul, Turkey, 2016.

28. Black Sea Memorandum of Understanding on Port State. In Port State Control In The Black Sea Region-Annual Report; Black Sea MoU: Istanbul, Turkey, 2017.

29. Black Sea Memorandum of Understanding on Port State. In Port State Control In The Black Sea Region-Annual Report; Black Sea MoU: Istanbul, Turkey, 2018.

30. Caribbean Memorandum of Understanding on Port State. In Caribbean Memorandum of Understanding on Port State Control-Annual Report 2014; Caribbean MoU: Kingston, Jamaica, 2014.

31. Caribbean Memorandum of Understanding on Port State. In Caribbean Memorandum of Understanding on Port State Control-Annual Report 2015; Caribbean MoU: Kingston, Jamaica, 2015.

32. Caribbean Memorandum of Understanding on Port State. In Caribbean Memorandum of Understanding on Port State Control-Annual Report 2016; Caribbean MoU: Kingston, Jamaica, 2016.

33. Caribbean Memorandum of Understanding on Port State. In Caribbean Memorandum of Understanding on Port State Control-Annual Report; Caribbean MoU: Kingston, Jamaica, 2017.

34. Caribbean Memorandum of Understanding on Port State. In Caribbean Memorandum of Understanding on Port State Control-Annual Report; Caribbean MoU: Kingston, Jamaica, 2018.

35. Indian Ocean Memorandum of Understanding on Port State Control. In Indian Ocean Memorandum of Understanding on Port State Control-Annual Report 2014; Indian Ocean: Dabolim, India, 2014.

36. Indian Ocean Memorandum of Understanding on Port State Control. In Indian Ocean Memorandum of Understanding on Port State Control-Annual Report 2015; Indian Ocean: Dabolim, India, 2015.

37. Indian Ocean Memorandum of Understanding on Port State Control. In Indian Ocean Memorandum of Understanding on Port State Control-Annual Report 2016; Indian Ocean: Dabolim, India, 2016.

38. Indian Ocean Memorandum of Understanding on Port State Control. In Indian Ocean Memorandum of Understanding on Port State Control-Annual Report 2017; Indian Ocean: Dabolim, India, 2017.

39. Indian Ocean Memorandum of Understanding on Port State Control. In Indian Ocean Memorandum of Understanding on Port State Control-Annual Report 2018; Indian Ocean: Dabolim, India, 2018.

40. Mediterranean Memorandum of Understanding on Port State. In Mediterranean Memorandum of Understanding on Port State Control-Annual Report 2014; Mediterranean MoU: Alexandria, Egiypt, 2014.

41. Mediterranean Memorandum of Understanding on Port State. In Mediterranean Memorandum of Understanding on Port State Control-Annual Report 2015; Mediterranean MoU: Alexandria, Egiypt, 2015.

42. Mediterranean Memorandum of Understanding on Port State. In Mediterranean Memorandum of Understanding on Port State Control-Annual Report 2016; Mediterranean MoU: Alexandria, Egiypt, 2016.

43. Mediterranean Memorandum of Understanding on Port State. In Mediterranean Memorandum of Understanding on Port State Control-Annual Report 2017; Mediterranean MoU: Alexandria, Egiypt, 2017.

44. Memorandum of Understanding on Port State Control for West and Central African Region. In Abuja MoU Annual Report 2014; Abuja MoU: Lagos, Nigeria, 2014.

45. Memorandum of Understanding on Port State Control for West and Central African Region. In Abuja MoU Annual Report 2015; Abuja MoU: Lagos, Nigeria, 2015.

46. Memorandum of Understanding on Port State Control for West and Central African Region. In Abuja MoU Annual Report 2016; Abuja MoU: Lagos, Nigeria, 2016.

47. Memorandum of Understanding on Port State Control for West and Central African Region. In Abuja MoU Annual Report 2017; Abuja MoU: Lagos, Nigeria, 2017.

48. Memorandum of Understanding on Port State Control for West and Central African Region. In Abuja MoU Annual Report 2018; Abuja MoU: Lagos, Nigeria, 2018.

49. The Paris Memorandum of Understanding on Port State Control. In Port State Control Annual Report-Adjusting Course; Paris MoU: Hague, The Netherlands, 2014.

50. The Paris Memorandum of Understanding on Port State Control. In Port State Control Annual Report-Safer Entry of Enclosed Spaces; Paris MoU: Hague, The Netherlands, 2015.

51. The Paris Memorandum of Understanding on Port State Control. In Paris MoU Annual Report "Seafarers Matter"; Paris MoU: Hague, The Netherlands, 2016. 
52. The Paris Memorandum of Understanding on Port State Control. In Paris MoU Annual Report "Safeguarding Responsible and Sustainable Shipping"; Paris MoU: Hague, The Netherlands, 2017.

53. The Paris Memorandum of Understanding on Port State Control. In Paris MoU Annual Report "Consistent Compliance"; Paris MoU: Hague, The Netherlands, 2018.

54. Riyadh Memorandum Of Understanding on Port State Control. In Riyadh Memorandum of Understanding on Port State Control_Annual Report 2014; Riyadh MoU: Muscat, Sultanate of Oman, 2014.

55. Riyadh Memorandum Of Understanding on Port State Control. In Riyadh Memorandum of Understanding on Port State Control_Annual Report 2015; Riyadh MoU: Muscat, Sultanate of Oman, 2015.

56. Riyadh Memorandum Of Understanding on Port State Control. In Riyadh Memorandum of Understanding on Port State Control-Annual Report 2016; Riyadh MoU: Muscat, Sultanate of Oman, 2016.

57. Riyadh Memorandum Of Understanding on Port State Control. In Riyadh Memorandum of Understanding on Port State Control-Annual Report 2017; Riyadh MoU: Muscat, Sultanate of Oman, 2017.

58. Tokyo Memorandum of Understanding on Port State Control. In Annual Report On Port State Control in the Asia-Pacific Region 2014; Tokyo MoU: Tokyo, Japan, 2014.

59. Tokyo Memorandum of Understanding on Port State Control. In Annual Report On Port State Control in the Asia-Pacific Region 2015; Tokyo MoU: Tokyo, Japan, 2015.

60. Tokyo Memorandum of Understanding on Port State Control. In Annual Report On Port State Control in the Asia-Pacific Region 2016; Tokyo MoU: Tokyo, Japan, 2016.

61. Tokyo Memorandum of Understanding on Port State Control. In Annual Report On Port State Control in the Asia-Pacific Region 2017; Tokyo MoU: Tokyo, Japan, 2017.

62. Tokyo Memorandum of Understanding on Port State Control. In Annual Report On Port State Control in the Asia-Pacific Region 2018; Tokyo MoU: Tokyo, Japan, 2018.

(C) 2020 by the authors. Licensee MDPI, Basel, Switzerland. This article is an open access article distributed under the terms and conditions of the Creative Commons Attribution (CC BY) license (http://creativecommons.org/licenses/by/4.0/). 